The Institutionalization of Fair Trade: More than Just a Degraded Form of Social Action Author(s): Corinne Gendron, Véronique Bisaillon and Ana Isabel Otero Rance Source: Journal of Business Ethics, Vol. 86, Supplement 1: Fair Trade (2009), pp. 63-79

Published by: Springer

Stable URL: https://www.jstor.org/stable/40294860

Accessed: 06-06-2019 16:26 UTC

JSTOR is a not-for-profit service that helps scholars, researchers, and students discover, use, and build upon a wide range of content in a trusted digital archive. We use information technology and tools to increase productivity and facilitate new forms of scholarship. For more information about JSTOR, please contact support@jstor.org.

Your use of the JSTOR archive indicates your acceptance of the Terms \& Conditions of Use, available at https://about.jstor.org/terms 


\section{The Institutionalization of Fair Trade: More than Just a Degraded Form of Social Action}

\section{Corinne Gendron Véronique Bisaillon Ana Isabel Otero Rance}

\begin{abstract}
The context of economic globalization has contributed to the emergence of a new form of social action which has spread into the economic sphere in the form of the new social economic movements. The emblematic figure of this new generation of social movements is fair trade, which influences the economy towards political or social ends. Having emerged from multiple alternative trade practices, fair trade has gradually become institutionalized since the professionalization of World Shops, the arrival of fair trade products in the food industry, and the establishment of an official "fair trade" label. With the strength that this institutionalization has generated, fair trade can now be considered a real trade system that questions, as much as it renews, the traditional economic system. In parallel, this transformation has exacerbated the tensions within the movement, which
\end{abstract}

This article is translated from the French by Annelies Hodge and revieused by Claire Valade.

Corinne Gendron is a professor in the Department of Organization and Human Resource Management within the School of Management Science at l'Université du Québec à Montréal (UQAM). She has headed the research chair in Social Responsibility and Sustainable Development Centre (CRSDD) since 2004, directing several research programmes on sustainable development, corporate social responsibility, globalization, new social economic movements, and fair trade.

Véronique Bisaillon is a Master's student in the Environmental Science institute at l'Université du Québec à Montréal (UQAM). She is currently uriting a thesis about fair trade and sustainable development while working as the Social Responsibility and Sustainable Development Centre (CRSDD) co-ordinator.

Ana Isabel Otero Rance is a PhD student in Political Science at l'Université du Québec à Montréal (UQAM). She has been uorking as a researcher at the Social Responsibility and Sustainable Development Centre (CRSDD) since January 2004. Her research focuses on fair trade as a development altemative, the conventional intemational trade system, and the influence of the new economic and social movements. can be characterized as a clash between a "radical, militant" pole and a "softer, more commercial" one. However, it is not the actual institutionalization of fair trade which is being debated among fair trade actors on either side of the fence, but rather the challenges inherent in finding an economic institutionalization acceptable to social economic movements. Therefore the institutionalization process of fair trade should not be seen as mere degradation of social action, but rather as typical of the institutionalization process of new social economic movements. If we need to worry about the highjacking and alteration of the fair trade movement by the dominant economic system, the opposite is no less likely, as new social economic movements contribute to an ethical restructuring of markets.

KEY WORDS: fair trade, globalization, institutionalization, new social economic movements, new social movements, social action

ABBREVIATIONS: ATO: Alternative Trade Organization; EFTA: European Fair Trade Association; FLO: Fair Labelling Organization - International; FSC: Forestry Stewardship Council; FTO: Fair Trade Organisatie or Fair Trade Organizations; IFAT: International Federation of Alternative Trade; ISO: International Organization for Standardization; FINE: informal umbrella of FLO, IFAT, NEWS!, EFTA; ILO: International Labour Organization; MCC: Mennonite Central Committee; NEWS!: Network of European World Shops; SAI: Social Accountability International; SERRV: Sales Exchange for Refugee Rehabilitation and Vocation; UCIRI: Unión de Comunidades Indígenas de la Región del Istmo; UNCTAD: United Nations Conference for Trade and Development

\section{Introduction}

Since the turn of the millennium, the fair trade movement has left its marginal beginnings behind, 
gaining an increasingly important notoriety despite the fact that its market share remains modest. Concurrently, it is experiencing tensions that are crystallized around an initial perspective, called "radical and militant", and a second one, perceived to be "softer and more commercial". These tensions are more and more apparent as the movement has become institutionalized or formalized through a common definition, common criteria, and, above all, a distribution strategy which is now symbolic of the two clashing perspectives. Some fear that the transformative potential of the fair trade movement could be weakened through this institutionalization as it is progressively cut from its roots and simultaneously "contaminated" by an economic or commercial logic.

Though this portrait may appear overdrawn, it does summarize the many contradictory positions in the fair trade movement which, according to some, is at the point of bursting. However, by placing fair trade within the larger context of the new social mobilizations, and the transformations that they are causing, which are manifesting themselves in the era of globalization, the existing conflict at the centre of the movement can be transcended such that the "militant" and "commercial" poles are seen in a complementary way.

The institutionalization of social movements took new forms in the era of globalization by systematically resorting to economic methods of pressure. "Political institutionalization" has been superseded by what could be defined as "economic institutionalization" - a formalization of demands in the economic system. This type of institutionalization is typical of movements that we call social economic, of which fair trade is one of the best known, and requires a new look at the process of social transformation in advanced capitalist societies. In this article, we demonstrate that, while this transformation is creating well-founded fears, the process of the institutionalization of fair trade does not have to be interpreted as a simple degradation of social action initially instigated by activists, but rather can be interpreted as typical of the mode in which new social economic movements are institutionalized.

The argument is built in four stages. First of all, we will trace the plural origins of fair trade, which offers an interesting and often neglected exploration of the current tensions within the movement. Next, we reflect on the recent evolution of the movement and the question it raises: does the institutionalization of fair trade correspond to a degraded form of social action, a weakened form of the movements' demands? To respond to this, we propose beginning with an understanding of the nature of social movements and the phenomenon of their institutionalization. We then reveal the concrete forms that the institutionalization of the fair trade movement has assumed over the last decades and the challenges it faces. In the last section of this article, we reflect on the institutionalization of fair trade and of new social economic movements in general, and how they manifest their transformative potential in advanced capitalist societies. Finally we conclude that it is not the institutionalization of fair trade as such that causes problems for the actors of the movement, but rather the mode of institutionalization. By proving to be more economic than political, this mode is typical of other social mobilizations which characterize the era of globalization, and is not less able to cause important social transformations.

\section{From charity to a parallel commercial system}

Many authors trace the origins of fair trade to craft boutiques which appeared in the United States, the United Kingdom, and the Netherlands in the middle of the 20th century. ${ }^{1}$ These initiatives not only came from political movements of solidarity known as the "solidarity trade" (IFAT, 2003), but also from development organizations known as "developmental trade" (IFAT, 2003), corresponding to the early history of a social movement that has multiple origins.

In effect, fair trade resulted from a serendipitous convergence of different local initiatives in alternative commerce. Firstly, although it has not always been acknowledged, fair trade has an incontestable relationship with the co-operative movement, which has its roots in nineteenth century Italy and the United Kingdom (IFAT, 2003) and with hundreds of later initiatives like those raised by Low and Davenport (2005). ${ }^{2}$ This movement aims to develop a co-operative economy that is integrated from the production to the distribution of products (IFAT, 2003): 
The conceptual bases of fair trade are well understood under the umbrella of social projects put in place by the pioneers of the cooperative movement. The founders of the Rochdale Equitable Pioneer Society had already developed the principle of eliminating the excessive profit of intermediaries. They also wished to transform the nature of commercial relations into a way for the civil society to organize itself while making the citizen-consumer an actor of social change. (Malservisi and Faubert-Mailloux, 2000, p. 2, our translation)

Secondly, fair trade can also be linked to another type of practice that came to the forefront of the solidarity movement after the Second World War: the charity business. Beginning in 1950, religious organizations and other NGOs had the idea of financing their development projects through the sale of craft products, at the same time aiding communities and refugees in the South as well as neglected populations in the $\mathrm{North}^{3}$ (Low and Davenport, 2005). In the beginning, there were no systematic links between the crafts sold and the communities who benefited from the assistance; this principle imposed itself towards the end of the 1950s (Low and Davenport, 2005).

Thirdly, fair trade can be linked to solidarity trade which emerged from the political movements of solidarity and which imported products from politically or economically marginalized Southern countries (Kocken, 2003; Renard, 2003) in the decades that followed, namely the 1960s and 1970s (Kocken, 2003). This alternative commerce was not so much based on the commitment of religious missionaries, but on that of activists who opposed capitalism and neo-imperialism by preaching alternative ways of life (Low and Davenport, 2005; Renard, 2003). Before contributing towards improving the quality of producers' lives, they wished to find outlets for the products of excluded countries (Renard, 2003; Malservisi and FaubertMailloux, 2000).

Finally towards the end of the 1960s, international development agencies and religious organizations initiated a "developmental trade", which consisted of assisting Southern producers in production and exportation (Kocken, 2003; Malservisi and FaubertMailloux, 2000). The international development organizations supported development objectives such as the eradication of poverty and aiding populations threatened by natural catastrophes (Kocken, 2003; Malservisi and Faubert-Mailloux, 2000), to which the celebrated slogan "trade, not aid", from the 1960s United Nations Conference for Trade and Development (UNCTAD), was applied. This slogan strongly portrays Southern demands for more just rules of commerce, without which aid is often rendered useless. It has since been reused as a slogan for a number of international solidarity networks (Solagral, 2002), ${ }^{4}$ with many fair trade actors today accepting it as the movements raison d'être.

These four different practices (see Figure 1) demonstrate the multiple origins of fair trade, which Le Velly refers to as the "trade of benevolence" 5 (2004). According to Le Velly, such commerce has two main characteristics. On the one hand, it is a niche commerce where buyers are already aware and convinced of the pertinence of the projects supported by their purchases; new buyers are not necessarily sought unless they are known to be already supporting similar causes. On the other hand, the product can be sold at a price higher than comparable conventional products, regardless of its quality. The purchase of benevolence trade products corresponds above all to an act of charity seeking to aid producers or support the political causes of Southern countries. We acknowledge and recognize

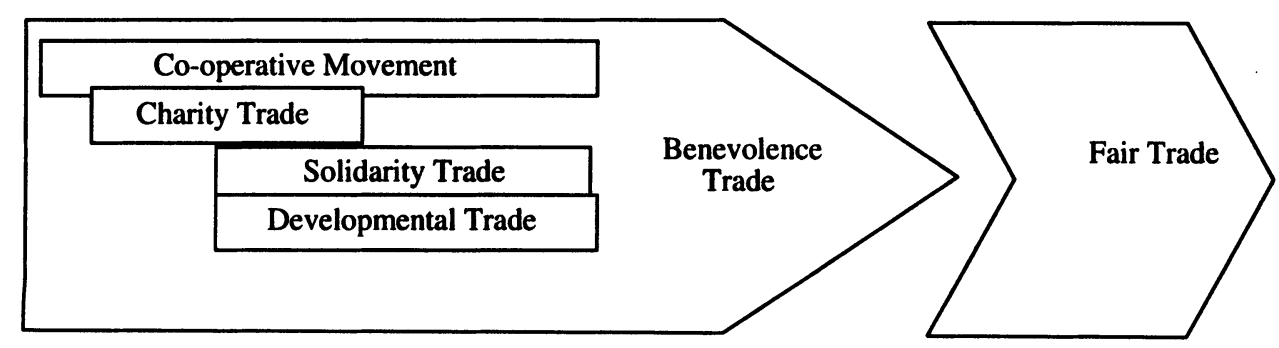

Figure 1. The movements at the origin of fair trade. 
these two ideological positions which still mark the fair trade movement today, and which, according to some, might even threaten to tear the movement apart.

The 1980s and 1990s marked a turning point when the different practices of benevolence trade consolidated themselves around the idea of a "just and equitable" alternative to conventional trade. This evolution occurred as a reaction to the commercial context at the time. Firstly, towards the end of the 1980s, the fair trade craft sector had to address several important difficulties. In terms of what was on offer, the arrival of new commercial players (such as Pier 1 Imports) and the rise of catalogue orders in ethnic products destroyed the exclusivity of the fair trade movement (Littrell and Dickson, 1999; Low and Davenport, 2005). In terms of the demand, the recession reduced consumer buying power, with people becoming more demanding regarding the quality of goods. Marketing, which the organizers of alternative commerce were largely not familiar with, became unavoidable while the products had to satisfy new international health and safety standards (Low and Davenport, 2005). This context encouraged a triple evolution of the movement, characterized by the "professionalization" of World Shops, the arrival of fair trade products in the food industry, and the establishment of the fair trade label.

By the end of the 1980s, World Shops were becoming more professionalized, through an emphasis on commercial activities, which began to take a place similar to information and education, and through improving the quality and the diversity of products being offered (Veit, 1997). The "professionalization" of alternative distribution networks accompanied the creation and consolidation of different fair trade networks, aiming to expand fair trade and position it in the political scene. The International Federation of Alternative Trade (IFAT), the European Fair Trade Association (EFTA), and the Network of European World Shops (NEWS!) are the principal examples.

Fair trade products also appeared in the food industry towards the end of the 1980s. Although the Dutch fair trade organization Fair Trade Organisatie (FTO) had already imported fair trade coffee for the first time from Guatemala in 1973 (Kocken, 2003; Veit, 1997), it was not until the end of the 1980s that the movement made a significant entry into this market. This change resulted from the needs of producers facing the coffee crisis, the necessity to counter difficulties within the craft sector, the rise of ethical consumerism, and the creation of the fair trade label (Low and Davenport, 2005).

Facing a limited alternative distribution network, in 1988 Dutch clergyman Frans Van der Hoff (i.e., Francisco VanderHoff Boersma) and Nico Roozen created the Max Havelaar association as well as the fair trade label carrying the same name. In parallel to the "professionalization" of alternative commerce networks through fair trade boutiques, a completely new strategy of distribution was born: labelling effectively opened the doors to large-scale distribution. This label originated from a reflection made by the peasants of the Union de Comunidades Indígenas de la Región del Istmo (UCIRI), as described by the founders of Max Havelaar. To have a real effect on the peasants' life, the sale of fair trade coffee was not just a matter of price but also of scale and volume: sold in small quantities, it remained only a symbolic policy. "For the peasants of UCIRI, the solution was evident: 'Our coffee must be sold in supermarkets at a fair price. Our coffee had to be within range of the average consumer, and made available specifically where they shop"' (Roozen and Van der Hoff, 2002, pp. 99-100, our translation).

It was through negotiations with a distributor that the promoters of Max Havelaar decided to establish a label instead of a brand name (Roozen and Van der Hoff, 2002, p. 109). The label's criteria were discussed by a commission which gathered together both distributors and Solidaridad, a development organization where Mr. Roozen worked. The introduction of Max Havelaar coffee in 1988 was a success and its market share rapidly reached 2 per cent. $^{6}$ This labelling system was adopted in Belgium two years later, followed by Switzerland in 1992. Other labels soon followed, such as: Fair Trade (the United Kingdom, Ireland, and Canada), Transfair ${ }^{7}$ (Austria, Germany, Italy, Luxemburg, Japan, the United States, and Canada), and Rättvisenmärkt (Sweden). In 1997, seventeen certification organizations joined together in an international federation, the Fair Labelling Organization-International (FLO). Today, national initiatives from Australia, New Zealand, and Mexico are also included. Through this federation, the labelling organizations gathered their resources by sharing their expertise 
and making their certification criteria uniform (Buccolo, 2000).

The wave of World Shop "professionalization", the arrival of fair trade in the food industry, and the development of a fair trade labelling strategy paved the way from altemative trade to fair trade. This change, which occurred in the $1990 \mathrm{~s},{ }^{8}$ had marketing aims, according to Low and Davenport (2005). "Alternative commerce" refers above all to a commerce that occurs on the margins of traditional commerce, taking on the characteristics of benevolent commerce, while "fair trade" proposes a new form of commerce with the specific aim of reserving a just price for producers (Low and Davenport, 2005). ${ }^{9}$ It is even more important to note, however, that this new name is within the same movement of practices sharing diverse origins that call themselves "fair". Also, the heterogeneity of fair trade is testimony to this plural heritage, even if many interpret it as a fragmentation of a movement that was once unified. Fair trade originates from a triple evolution that has led to its institutionalization which, while guaranteeing its success according to some, has cut it off from its roots, leading to a loss of significance and transformative potential according to others. It is precisely this question that we propose to reflect upon in this article: Has the institutionalization of fair trade cut it off from its social roots to the point that we can no longer speak of a social fair trade movement? In order to respond to this, it is important, firstly, to recall the difficulties posed by the institutionalization of social movements and, secondly, to study the particular challenges that this institutionalization poses for the fair trade movement. Finally, we conclude the article by demonstrating that the debate is not so much concerned with the effect of the institutionalization of the fair trade social movement, but rather on how it should be achieved.

\section{The institutionalization of fair trade}

At the turn of the twenty-first century, fair trade actors arrived relatively easily at a common definition of fair trade envisaged as, above all, an alternative to the traditional market in opposition to usual economic practices:
Fair Trade is a trading partnership based on dialogue, transparency and respect, that seeks greater equity in international trade. It contributes to sustainable development by offering better trading conditions to, and securing the rights of, marginalized producers and workers - especially in the South. Fair Trade organizations (backed by consumers) are actively engaged in supporting producers, in raising awareness and in campaigning for changes in the rules and practices of conventional international trade. (EFTA, 2001)

Fair Trade's strategic intent is to:

- work deliberately with marginalized producers and workers in order to help them move from a position of vulnerability to one of security and economic self-sufficiency;

- empower producers and workers as stakeholders in their own organizations;

- play a wider, active role in the global arena in order to achieve greater equity in international trade. (FINE, cited in EFTA, 2001) ${ }^{10}$

Fair trade poses itself as an alternative to the traditional trade system which it denounces as oligopolistic and inequitable. It proposes an alternative way to trade by establishing a series of principles at the base of commercial relations. Relationships are no longer a question of compromises reached through economic agents who are looking to justify a certain marginal utility, but rather a question of people who are anchored in specific societies and who, through commercial transactions, seek to establish a real relationship of solidarity. This relationship of solidarity takes form through an alternative commercial framework that is situated on the margins of traditional markets. It is based both on principles and new institutions: "The idea of the 'invisible hand' has given way to the idea of working 'hand in hand,' the market is regulated by democratic authorities" (Lemaigre and Verbeeren, 1997 in Bowen, 2001, p. 25).

Regarding principles, fair trade defines several criteria, several of which address producers and others of which address Northern organizations. Generally, the producers must guarantee that their organizations have democratic decision-making procedures and operations (Bowen, 2001). More specifically, the FLO defines two series of criteria for producers: those which apply to small producers and 
those which apply to workers in plantations or industries (FLO, 2004). In the first case, the producer must function either in co-operative form or in another form of participatory and democratically structured organization. In the second case, employers must pay decent salaries to workers', guarantee the right of workers to unionize, and offer adequate lodging if applicable. They also have to respect health, safety, and environmental standards. Finally, forced labour and child labour are forbidden (FLO, 2004).

There are two levels of producer criteria: firstly, minimum standards that must be respected in order to obtain certification; and, secondly, progressive standards which encourage producers to continually improve working conditions and product quality as well as the environmental sustainability of their activities or their investment in the development, the organization, and the well-being of workers (FLO, 2004).

Organizations in the North, that is, buyers, must respect the following guidelines:

- to provide direct access... to producers' products, avoiding - to the greatest extent possible - middlemen and speculators (Bowen, 2001, p. 25);

- to pay a fair price for the products that covers the basic needs of producers and production costs, and also leaves a margin for investment;

- to pay part of the price (40-50 per cent) in advance so that producers can purchase the necessary raw materials to complete an order without falling into debt;

- to establish long-term working relationships and contracts with producers.

Specific criteria concerning the quality, procedure, or price may be added to these generic ones depending on the product. ${ }^{11}$ The trade partners may also agree to a series of other criteria, such as the application of a sustainable perspective, the diversification of production, the respect of the conventions of the International Labour Organization (ILO), the security of local food, the balance between local and export market access, and the act of favouring local transformation of products (Bowen, 2001, pp. 29-30). As for Northern organizations, they may offer technical assistance, financing and training, and organize educational campaigns to raise awareness among Northern consumers. They may also promote more advantageous international commercial rules for Southern countries.

In the fair trade system, the criteria are complemented by two distinct distribution strategies: an alternative commercialization network, that is, shops, which offer fair trade products exclusively; and fair trade labelling, which permits the identification of fair trade products sold on the traditional market. The first strategy is part of what we have described as the prehistory of fair trade, at which time the initiators of the movement began to offer products from the South in specialized shops run by activists and volunteers. Since these beginnings, such shops have developed from meeting points to more professional selling spots, structured through the formalization of operating rules and the establishment of national organizations or networks. These shops are now connected to central merchandizing networks (the Alternative Trading Organizations [ATOs] or Fair Trade Organizations [FTOs]), which work directly with Southern producers and guarantee the respect of fair trade criteria regarding the products that they import.

In alternative distribution networks, the development of markets is paramount. Crafts are the principal products that are being commercialized in the fair trade network. This presents a particular challenge because it relates to a sector where sales possibilities are limited. Such products are purchased occasionally, compared to food products that are consumed regularly. Also, the renewal of products is crucial in this sector, a criterion that few fair trade producer groups can satisfy.

The alternative network has created its own strategy for assuring the credibility of its distribution system, a form of fair trade institutionalization. Compared to labelled food products, craft products are involved in a longer production chain. The certification model of fair trade products that is used for food products cannot be used for craft goods aimed at penetrating large distribution networks, as controlling the more complex chain of value is very difficult. After the 6th biennial conference of IFAT in Tanzania in 2001, proper standards for such fair 
trade organizations were established ${ }^{12}$ regardless of whether they were producers, distributors, exporters, importers, or retailers. IFAT also established a three-step monitoring system to allow for verification of these criteria among its members. ${ }^{13}$ Finally, in 2004 IFAT launched the "FTO Mark", which is a label provided to IFAT member organizations after successful monitoring. This label aims to reassure consumers, conventional trade actors, and political authorities about the commitment of these members towards fair trade (IFAT, 2004). It is therefore not a certification for the products of organizations but rather for the organizations themselves.

This labelling has allowed fair trade to penetrate the market by infiltrating conventional distribution channels. It should be noted that this distribution strategy had profound repercussions on the definition and the practices of fair trade, opening the way to real paradoxes that are causing concerns and tensions within the movement. As we have demonstrated, the introduction of the fair trade label was a response to a simple logical premise: If the fair trade movement really wishes to support Southern producers, it must focus on volume, without which results remain marginal and insignificant. The greater the volume of fair trade products, the more producers will be able to benefit from its advantageous conditions. The rising volume of sales raises commercial challenges regarding product access:

To be efficient, we must effectively assure that our consumers have an optimal access to the products we promote. This means, in practice, that alternative commerce can only be a real alternative if products are available in every supermarket, every grocery store, on every street corner, in places of business where consumers shop, and not only in specialized World Shops, where alternative trade products are generally sold. (Transfair, 2001, our translation)

Widespread access to fair trade products broadens the client base, moving it from a restricted circle of activists to the larger segment of consumers who are aware or conscious of the situation. It is only through conventional distribution channels that this larger market can be reached; it is therefore necessary to infiltrate these channels by reaching agreements with large distributors. The labelling organizations themselves are not against collaborating with traditional economic actors, as they recognize that they offer a more efficient means to assist the greatest number of Southern producers possible.

For labelling organizations, co-operation between fair trade actors and traditional actors is a win-win strategy:

It is in the interest of all actors in a society that new and efficient models are established, which help address the general gap between the rich and the poor, based not on charity, but on fair exchanges and dignity. In truth, the interests of Third World producers coincide with the long-term interests of consumers, commerce, industry and the governments of those countries. In the case of coffee, we are convinced that coffee merchants, roasters and supermarket chains can, and must, play a crucial role based on converging interests. (Transfair, 2001, our translation)

Labelling organizations have also focused on addressing another commercial problem: the quality and image of fair trade. By associating themselves with well-known brands of roasters, fair trade labels could not only benefit from their knowledge but also from their image of quality, thus overcoming prejudices concerning the "solidarity" coffee (Renard, 2003, p. 90):

For the lasting success of our common objectives, it is crucially important to combat all the widespread prejudices relating to alternative trade. The coffee offered by small producers is excellent, small producers are trustworthy commercial partners, and roasters and coffee merchants are not necessarily exploitative. We must construct a public image of quality and trust regarding fair trade. (Transfair, 2001, our translation)

Reading such statements, one notes that resorting to the labelling process and to large distribution networks as a favoured strategy marks a new orientation in fair trade; it is no longer an alternative to the conventional market, it is an option within that market: "Alternative trade must develop itself within 'normal' trade", Transfair noted on its Web site (2001). In short, the "intention of the Fair Trade labelling organizations was to create a reality within the market, instead of constructing an alternative outside the market" (Renard, 2003, p. 90).

It is this positioning with regard to the conventional market that causes the greatest tensions within the fair trade movement. As the founders of Max Havelaar state, the idea of introducing fair trade 
products through large distribution channels caused distrust and reservations among fair trade actors. ${ }^{14}$ Even though labelling reached the entire movement, tensions between actors focusing on volume (which preceded the creation of the label) and actors focusing on alternative distribution networks remain:

Though blurred by the uniform term "Fair Trade", tension remains between two visions: One, a more radical conception that sees "fair" trade as a tool for modifying the dominant economic model, and the other, more pragmatic, that emphasizes the insertion of products from the South under fair conditions in the markets of the North.... For the first group, more politically and ideologically linked to militant movements, the label is merely a tool of transition, and the challenge consists of making fair trade the general rule. Thus, it is an alternative to the dominant model or, in other words, the aim is to make all exchanges fair. The second group attempts to penetrate the market and the lifestyle of consumers in order to sell larger quantities of fair products and to strengthen the producer organizations of the South, demonstrating by this route that the dominant model is not monolithic (Renard, 2003, p. 91).

For those who participate in alternative distribution networks, collaborating with large distribution channels is contrary to the principles and the alternative ideology of fair trade. Furthermore, providing access to fair trade products in supermarkets risks standardizing what was meant to be consumption aimed at activists. Even Max Havelaar members agree that the commercialization across large distribution channels required a change in the fair trade message: "To broaden the spectrum of the public interested in buying these products, it was necessary to appeal more to humanitarian sentiments than to political convictions" (Renard, 2003, p. 90). One can therefore ponder the emergence of an apolitical, ethical consumption where the equitable dimension of the product is concerned less with the denunciation of an international trading system which is unjust and is instead more focused on simple qualitative attributes, as with organic, home-made, or cholesterol-free products. In short, is fair trade aiming to transform the rules of international commerce by educating the public about the establishment of an alternative, or is it simply aiming to respond to the demand of a new wave of ethical consumers? Behind this question lies the unavoidable paradox that occurs when a social movement integrates itself within the economic arena:

The tension does reflect ... a real ambivalence of the Fair Trade Labeling Model, one that acts both inside and outside the market, a contradiction between the identity of the groups linked to activism and their reality as business. Indeed, "equity" products respond to commercial logic from the moment of their insertion into the market: what is "ethical" is a selling point and profits come from the social significance the products carry. That is, these products occupy a niche in the market, but this niche also responds to a logic contrary to market logic in that the way it escapes purely mercantile considerations. (Renard, 2003, p. 92)

This ambivalence between the militant identity and the reality of the business does not limit itself to the labelling strategy. Specialized fair trade shops also occupy a place in the market, and are therefore subject to a typical commercial logic that has modified their relationship with the conventional market:

Ironically, since World Shops, which form a large part of the social base of alternative trade organizations (ATOs), have seen their sales double and even triple as a result of advertising and national labelling campaigns, they have been pushed to become more efficient and are less inclined to criticize conventional business practice as they were in the past. (Thomson cited in Malservisi and Faubert-Mailloux, 2000, our translation)

In short, while seeking to utilize trade for militant ends, does the fair trade movement not inevitably run the risk of diluting its own cause for commercial ends? Partnering with conventional economic actors already requires compromises between ethical principles and commercial considerations, and one can fear that the desire for an even larger presence on the market may be achieved to the detriment of the values and ideology of fair trade (Renard, 2003, p. 92). The second danger is the highjacking of that ideology by large actors within the conventional market who, due to their interest in the growing segment of responsible consumers, decide to offer their own "fair trade" products without necessarily 
responding to the strict requirements defined by the movement. As is already the case in the food industry where all sorts of labels proliferate, the multiplication of fair trade labels risks causing confusion and undermining fair trade. This is the reason why the movement is lobbying for the fair trade label to be protected by official institutions, as is the case for the certified organic label. In fact, these questions highlight the concerns caused by the institutionalization of fair trade, an institutionalization that no longer solely operates in the political sphere as envisaged by both traditional and new social movements, but also in the economic sphere, thus justifying the concept of "new social economic movement".

\section{Social movements and institutionalization}

Fair trade is generally presented by its actors as a social movement which claims greater justice for Southern countries. The character of the fair trade social movement can be understood in several ways depending on the theoretical perspective chosen. Over the last decades, a number of theories about social movements have been formed, with the principal schools being resource mobilization and new social movements. The school of resource mobilization considers social movements as interest groups which fight among themselves so that demands are recognized and integrated by the official apparatus, that is, so that they are institutionalized. This perspective sees social movements from a strategic and utilitarian perspective that, while interesting, does not allow for an understanding of mobilizations centred on normative projects or universal principles (Cohen, 1985) such as fair trade, because, within this perspective, social action is strictly viewed as defending private interests within an organizational structure (Gendron, 2005).

The school of new social movements appears more appropriate for understanding the phenomenon of fair trade. It defines social movement as the collective control of an alternative societal project, a fight that is not directed towards the State but against a social class opponent. This struggle seeks to control the historicity, that is, the means by which a society acts upon itself and through which actors strive to merge with the normative foundations (Touraine, 1978a). According to the actionalist perspective, the specificity of new social as compared to traditional working-class movements rests in the fact that their social base "is constituted mainly of a new middle class that is exhibiting more of a class sensibility than a class consciousness so that, while possessing a structurally determined potential for mobilization, its demands are either very specific, or universalist, and in any case utterly foreign to the notion of class specificity" (Gendron, 2005, p. 399, our translation). Finally, the work of new social movements may create demands for institutions, but it is at the level of historicity, that is, of society's cultural orientations, instead of the institutional level, that their essence as social movements is expressed (Touraine, 1978b). The school of new social movements thus disassociates itself from the theory of resource mobilization which is completely oriented towards the quest for State institutionalization. For Touraine, institutionalization appears to be a degraded form of the social movement's action and the movement thus seems transformed by this process:

The study of social movements shows that, after an initial phase of global opposition between competing utopias, a phase of direct confrontation between the social adversaries occurs, followed by a phase of institutionalization of the conflict .... This type of institutionalization cannot operate without a transformation of the actors or without the intervention of political forces.... (Touraine, 1973, p. 241, our translation)

For other actionalist authors, the question of institutionalization poses itself differently depending on the nature of the demands of new social movements and the framework of political representation. As demonstrated by Melucci, organizational forms of new social movements escape traditional political categories, corresponding in their latent phase to "a nebula of variable density, with unclear borders", and they become explicit only in moments of mobilization by which they cannot be defined (Melucci, 1983, p. 13, our translation). Thus, on the one hand, political organizations answer more to stable interests that rest on a clearly defined social base. On the other hand, social movements risk fragmenting and disappearing without a certain form of political representation. For Offe, the inability of political systems to accept the demands of new social 
movements is the very reason why these movements deploy their resources in non-institutional fields, outside of the State (1985). The question of the "institutionalization" of social movements does not take into consideration the transformations that they evoke, which, as explained by Eder, touch both the institutional and the non-institutional fields:

The commonplace that social movements are undergoing a process of institutionalization (which normally means integration into existing political and social institutions) has at least to be corrected. Institutionalizing social movements has led to effects that are changing the institutional system itself .... [Social movements] represent a new type of institution which forces the institutional system to adapt discursive structures. (Eder, 1993, pp. 16-17; 19)

According to the theories that we have presented, the institutionalization of social movements can thus be explained in three ways: in terms of the mobilization of resources, it corresponds to both the recognition of the interests of actors and the integration of these same interests into the political structure; according to Touraine, as it formalizes social conflict within the political system, institutionalization corresponds to a degraded form of social action which loses its transformative potential. Lastly, if we extrapolate from Eder, Offe, and Melucci, we could posit that the issue of the institutionalization of social movements needs to find transcendence in order to realize their transformational potential for institutional structures. Even if these theoretical perspectives seem contradictory, they at least shed light on the fair trade movement and also on its strategies and on the tensions that are crystallizing within them. The first perspective takes into consideration the reservations that international economic authorities have towards this movement, which aims to transform commercial rules and make them more just in relation to Southern countries. The second perspective takes into account the fears of a part of the movement which sees this "economic" institutionalization as degrading social mobilization and weakening its political message communicated to the authorities of world economic governance (an issue which we will return to later in this article). The third perspective allows an understanding of the transformations that fair trade causes, as it is no longer restrained within the "traditional" institutional sphere of world politics and instead is able to influence the rules of economic systems. These last two perspectives open the way for a new social economic movement; which we will explore after presenting the concrete forms that the institutionalization of fair trade has recently taken.

\section{The institutionalization of new social economic movements}

Over the past few years, a new mode of social action has caught the interest of many researchers: the use of economic mechanisms to respond to social demands. Micheletti, for example, developed the concept of political consumerism (2003), while Cashore proposed the expression "Non-State Market-Driven (NSMD) Governance Systems" to explain the systematization of economic forms of social pressure (2002). Thus, following the new social movements, which broadened their action beyond the political sphere to the social sphere at the end of the 1960s, today's social movements focus primarily on the economic sphere (Gendron, 2001). To reinforce the actionalist heritage of our theoretical perspective, we have chosen to develop the concept of the new social economic movement. We present it as a new generation of the social movement, not in its essence as such but more through its methods of action, which involves different tools that have become refined and diversified over the years. Boycotting campaigns have been replaced by buycotting strategies (see Micheletti, 2003), based not only on the education and awareness of consumers but also on measures of traceability and labelling. Initiated by religious communities, ethical investment and its strategy of negative filtering in the selection of investments or threats of disinvestment have paved the way for socially responsible investment based on both filters and dialogue with the management of businesses. In both cases, we observe that social movements use economic status (that of the consumer or the investor) to pressure businesses on a socio-political level. They adapt the economic mechanisms, modelling them according to their values. In short, the arrival of social movements in the economic sphere leads to a redefinition, a re-politicization, and a re-socialization of economic transactions, thus regaining its status as a real social 
relationship so that it may be analysed and judged as such.

It is interesting to note that the arrival of social movements in the economic sphere is concomitant with the sudden preoccupation with social responsibility that companies have had over the last few years. A marginal concern during the late 1970s, referring to social responsibility when presenting the activities of a business to the public, has now become the rule (Stark, 1993). We no longer count the number of initiatives taken by companies to demonstrate their social responsibility and their corporate citizenship. The value of this process depends, however, on the credibility of the company. Only alliances with civil groups may guarantee, in the public eye, the veracity and legitimacy of a company's socially responsible actions that go beyond its original mandate and mission as a private, large-scale company. In the forestry sector, for example, companies that are certified ISO 14001, an essentially industrial standard, will aim towards sustainable management of their forests in order to qualify for the FSC certification, a more demanding standard developed by NGOs (Maurais and Lafrance, 2003). In the textile sector, some enterprises try to obtain the SA 8000 certification from Social Accountability International (SAI) to demonstrate their respect of fundamental human and worker rights, and to prepare themselves for verification by local NGOs (O'Rourque, 2000, p. 15). Far from isolated examples, these two cases demonstrate how a new dynamic is structuring the market on the basis of values. Social responsibility has become more than a differentiation criterion in terms of marketing; by reaching into the socio-political scene, it has become the necessary ingredient to legitimize companies whose sphere of influence has greatly expanded thanks to the process of the merchandizing of social issues (Champion, 2003).

The incursion of social movements into the economic arena thus appeared to be a countermeasure for the merchandizing processes that were penetrating the most hidden spheres of our lives - after all, political consumption takes root in consumer societies. However, this incursion is also linked to the transformation of regulatory methods inherent in the process of globalization and the redefinition of official institutions. Responsible consumption is often presented by actors within the social movement as the most efficient means to state one's beliefs considering that those of us in the North consume every day but only vote once every four years. ${ }^{15}$ In addition, responsible consumption influences practices beyond the national jurisdictions to which a citizen is subjected, thus presiding over a real globalization of social mobilization. Nevertheless, political consumption is not an alternative to traditional political action; it is used as a complementary strategy to more traditional forms of political activity, with responsible consumers also being highly active citizens within traditional political institutions (Stolle et al., 2003). In short, it is not the consumer who takes the place of the citizen, but rather the citizen who stands behind the consumer, with the limits and the potential that this status offers. In addition, political consumerism is also based on a system of traceability and labelling, which requires the intervention of the State to incorporate fair trade conditions within existing economic mechanisms and institutions; thus "political institutionalization" is needed to support "economic institutionalization".

According to Offe (1985), citizens seek to construct political action within society in order to express demands, through new social movements that remain unsatisfied by the system of the welfare State. Thus, to follow up on that thought, it appears that new social economic movements have become a means for citizens to construct political action within the market where unsatisfied demands on the political system can be expressed in the era of globalization. In addition, in response to Eder who argues that new social movements have transformed public space with a new logic of institutional action that supports forms of self-organization beyond the State (1993), we can note that new social economic movements are transforming economic space with a new logic of action that supports forms of selforganization in the market within which the institutional system must position itself. In light of this theoretical perspective, one can reflect on the most recent evolutions and tensions that exist within the fair trade movement, at a time when several fear that fair trade is becoming a degraded form of its original incarnation and losing its power of transformation.

Together with shareholder activism, fair trade is certainly the most symbolic of the new social economic movements. As for other movements, its action cannot be seen strictly in economic terms 
because it is mainly from the social and political spheres that it draws its raison d'être. Strict economic analysis, as proposed by some authors, offers limited interest as it concludes that fair trade, based on its very modest market share, plays only a marginal role (Perna, 2000, p. 365). While we cannot ignore the fair trade market when evaluating its impact on NorthSouth relations, other parameters, like the impact on the workforce, show the ratio of fair trade to international trade as being not 1 to 10,000 but rather 1 to 150 (Perna, 2000, pp. 360-361). In our opinion, the real impact of fair trade on international trade is best demonstrated in terms of quality rather than quantity.

[The] implications [of fair trade] go well beyond its own sales .... [It is] a permanent awareness campaign encouraging consumers to pay a just price for the products they buy, where social and environmental costs are included in the price, and working and social conditions as defined by ILO standards are respected. (Barratt Brown and Adam, 1999, p. 116, our translation; see also Bowen, 2001)

The existence of fair trade itself serves as an ethical reference, fixing the standards of social responsibility by which large businesses and their operations are now judged. The more we educate Northern consumers about international trade issues and North-South inequalities, the more important this normative role becomes:

Its power [i.e., the power of fair trade] clearly emanates from the social relationships that sustain it, which constitute its social capital, and from the strength of the [fair trade] label, its symbolic capital .... It is essential, therefore, to preserve the relationship between the "equity" market and the social organizations that incubated it. "Without the original linkage to social movements, alternative products lose their capacity to affect consumer's and producer's identities, and therefore the capacity to generate social change". (Brunori, cited in Renard, 2003, p. 94)

The qualitative impact of fair trade is therefore a tribute to the work of activists who dedicated themselves to awareness campaigns, and can thus be measured in terms of notoriety rather than market share. In this regard, it is interesting to note that the rate of awareness has often exceeded 50 per cent in certain countries, and as much as 80 per cent in the Netherlands.
However, this capacity is also intrinsically linked to the performance of fair trade with regard to its main objective: the development of Southern communities. One must note that only a small number of Southern producers have access to the fair trade network, and that often only a part of their production is distributed as fair trade. The portion of the product sold through the fair trade market provides the producer with stability and the ability to predict revenues, as well as providing access to prefinancing programmes or a bonus that can be reinvested in his or her organization and in community development (Barratt Brown and Adam, 1999, p. 115). The price offered within the fair trade network can also have an effect when average prices offered to producers in the traditional market rise. However, the impact of fair trade goes beyond the bonus offered for fair trade products. Integration into the network requires organizational criteria such as the implementation of a democratic structure as well as reinvestment in individual development in the organization and in the community. These requirements strengthen producers, placing them in a better position to negotiate with their traditional intermediaries, or even to bypass them in certain cases (Auroi, 2000, p. 205). Finally, integration into the fair trade network often allows access to new techniques and knowledge, improving the quality of production and reinforcing the competitiveness of producers in the market. These advantages all contribute towards empowering Southern producers and improving their position in the international marketplace. But is this the only ambition of fair trade? This would mean that fair trade is only a tool for correcting market imperfections which restrict Southern economic actors from fully benefiting from free trade (Perna, 2000, pp. 363-364).

By fixing the objective of aiding neglected Southern communities through the establishment of more just commercial rules, fair trade raises certain fundamental questions. The first is to know if development necessarily occurs through trade. By emphasizing exclusively the reinforcement of the trade positions of Southern producers, does fair trade not risk deepening the actual inequalities of international trade, thus encouraging specialization and dependence on cash crops at the expense of food crops? Must fair trade continue to encourage a commercial situation whereby Southern countries 
supply exotic products to their Northern counterparts to the detriment of their own food security? Finally, what position should fair trade take regarding the transport of food products over long distances within the perspective of sustainable development? Divergent opinions within the movement regarding these questions highlight the tensions between its "militant" and "commercial" wings. For many, fair trade must, above all, be thought of in terms of local development, favouring "local commercial flows, as demonstrated in the criteria proposed by certain certification organizations. The impact may also be seen in the long run in terms of its progressive separation from a dependence on exportation, and thus on the fluctuations and variations in the demand coming from foreign Northern markets" (Bucolo, 2003, p. 115, our translation). In light of this, we can understand initiatives like Commercio Justo, a Mexican fair trade label for Mexico, and also make a beneficial comparison between the fair trade movement and Northern initiatives such as community-supported agriculture. To sum up, the question that remains is:

How can one not be an accomplice to the great world bazaar? This is where the great challenge of fair trade resides. In a way, it should aim to destroy itself, in the sense that it should contribute to the reconstruction of broken Southern societies and encourage, for example, the re-conversion of speculative crops delivered by world commerce towards food crops necessary to feed famished local communities. Also, it must incite the craft industry to respond to the needs of local clients rather than exporting its trinkets to Westerners thirsty for exoticism. (Latouche, 2000, p. 352, our translation)

The fair trade movement could address these delicate contradictions by accompanying its action with a reflection on its objectives and the ways it intends to achieve them. Considering its roots in the social movement with its socio-political character, such a reflection cannot be avoided. Some fair trade organizations, such as Équiterre, ${ }^{16}$ are already doing this. Équiterre made the deliberate choice not to promote the importation of certain food products that are also produced locally in Québec and thereby adhere to 3N-J principles: Nude, Natural, Not-far and Just (Waridel et al., 1998). ${ }^{17}$

In short, one must recognize that the incursion of militant action in the economic arena is not without risk, and that commercial logic may alter social movements. However, the opposite is also true: The market can be transformed by the arrival of new actors responding to different market logic and free from a typical economic rationality. Following the example of other new social economic movements, fair trade contributes to the ethical restructuring of the market by imposing a framework of reference which will inevitably confront traditional economic actors. Fair trade criteria also impose themselves as the criteria to which many companies engaged in international trade and claiming to be responsible should aim for and by which they will be judged. Fair trade transforms economic institutions, seeking to institutionalize its economic governance while its actors demand greater equity in North-South exchanges. It is therefore not the institutionalization of the movement as such that poses a problem for certain factions of the movement but rather how this should occur; while a certain faction of activists perceived as more radical wish that the institutionalization restrict itself to political institutions, thus remaining marginal from the economic point of view, the majority appear committed to the idea of an "economic institutionalization", in full understanding of the risk that capitalism and its key actors may claim it for themselves. Balancing this double process of institutionalization certainly represents the greatest current challenge of the fair trade movement that draws an unquestionable force from its unity.

\section{Conclusion}

During the era of trade liberalization and globalization, a new form of social action has emerged to find, in the economic sphere, a way of expressing demands that are not addressed by official national authorities. The transformations caused by this social action are evident, not just through the implementation of public policies, but also in the economic system. Even if the market continues to function according to a certain immutable logic, like profit maximization, it and its actors are no less transformed by the actions of these new social economic movements.

The emblematic figure of this new generation of social movements is fair trade, which focuses its demands around a more just and advantageous 
trading system with Southern countries. Since its institutionalization in the 1990s, fair trade has become a true commercial system which questions as much as it renews the traditional economic system, while offering producers up to double prices for their harvest. This system drains the opportunistic, competitive ideology through which the dominant economic actors justify offering ridiculous prices to Southern producers. However, these same actors are now adapting in order to reach the niche of consumers who are conscious of ethical issues. This "economic institutionalization" worries a faction of the fair trade movement which sees it as an act of highjacking, which dilutes their message of justice and weakens, if not destroys, fair trade's power to transform. Whether political or economic, this institutionalization has the power to transform and, as demonstrated in studies on working-class movements, it does not destroy the social movement that drives it even with the modification of its discourse and strategies.

In this perspective, one must understand the current tensions within the fair trade movement; it is not the actual institutionalization of fair trade which is being debated but rather the challenges inherent in finding an economic institutionalization acceptable to social economic movements. However, this institutionalization does not replace political institutionalization and the transformations which it entails do not manifest themselves in the same manner. One cannot deny that, even if new social economic movements like fair trade may produce less spectacular transformations than an improbable revolution of international commercial rules and worldwide economic governance, they are no less capable of provoking transformations. Thus, companies must now work with a definition of their social performance fixed not only by their public relations specialists but also by myriad NGOs comprising both Southern actors and Northern activists. The new social economic movements also participate in an ethical restructuring of the market, such as fair trade, through which the treatment of Southern producers can be used as a commercial differentiation factor. Trade logic and social responsibility can thus converge while supporting strategies for more political institutionalization and reinforcing the process of transforming the rules of international trade.

\section{Notes}

1 At the end of the 1940s, Sales Exchange for Refugee Rehabilitation and Vocation (SERRV) and the Mennonite Central Committee Self Help Crafts offered Americans crafts that came from poor Southern communities, with sales helping to finance development projects (Bowen, 2001, p. 23). A decade later, Oxfam U.K. had the idea of selling pincushions and other products made by Chinese refugees; at the same time, a Dutch Catholic association sold Southern products via correspondence, an initiative that was the origin for the first "World Shop", which opened in Breukelen, Netherlands, in 1969 (Veit, 1997).

2 Low and Davenport (2005) highlighted different initiatives aimed towards creating international trade alternatives that can be traced back to the Indian cooperatives and Khadi movements of the 1920s. The Khadi movement promoted self-sufficiency and the boycotting of exported goods (Office of the Commissioners for Khadi and Village Industries, 2005).

3 SERRV was created in 1949 with the objective of aiding European refugees after the Second World War. Cuckoo clocks were imported from Germany to Maryland and sold in the United States. Later, the organization focused on importing crafts from developing countries (SERRV, 2005). The first activities of the Mennonite Central Committee (MCC) in the United States (which became Ten Thousand Villages in 1996), Oxfam U.K., and the S.O.S. organization from the Netherlands, also joined the wave of charity trade.

4 For example, in the Netherlands towards the end of the 1960s, a group of Dutch activists sold sugar cane from the Third World with the message: "In buying sugar cane, you assist populations from poor countries to have a place under the sun of prosperity" (Kocken, 2003, p. 1).

5 In reference to the benevolence of Adams Smith's butcher.

6 These results are nonetheless well below those indicated in the market studies used by promoters, which promised a market share of between 7 per cent and 14 per cent (Roozen and Van der Hoff, 2002, p. 121).

7 An initiative of EFTA.

8 Malservisi and Faubert-Mailloux (2000) estimated that this change in terminology occurred in the 1980s.

9 Even though today we speak more about fair trade than alternative trade, this change is still a subject of debate within the movement. For example, at the IFAT general assembly in 2005, members were against a name change which would have integrated the term "fair". 
The stakes of this name change were also discussed during the previous general assembly. Surprisingly, however, IFAT's Web site uses the name "International Fair Trade Association" instead of "International Federation of Alternative Trade". Despite such differences of opinion within the movement, changes in terminology mark the emergence of a trade which may now be considered as a sector in its own right (Malservisi and Faubert-Mailloux, 2000).

10 This definition was created by the FINE network (created in 1998), which, like the Fair Trade Advocacy Office, unites the large international fair trade organizations (FLO-I, IFAT, NEWS!, and EFTA) (EFTA, 2001).

11 The FLO defines several standards for each of the following products: bananas, cocoa, coffee, dried fruit, fresh fruit and vegetables, honey, juice, nuts, rice, spices, sugar, tea, wine, and even sports balls (FLO, 2004).

12 These standards are: the creation of opportunities for economically disadvantaged producers within the conventional system; transparency and accountability in management and commercial relations; the reinforcement of producer capabilities; gender equality; safe and secure working conditions; restrictions on child labour (the tasks being performed may not compromise their well-being, their security, or their education); the improvement of environmental practices; the payment of a just price that covers the cost of socially and environmentally sustainable production; and the promotion of fair trade (IFAT, 2004).

13 The first step is a self-assessment that organization members conduct biennially, based on a guide provided by IFAT. The second stage is a mutual review with members sharing their self-assessment reports with their commercial partners. Finally, an external evaluation is conducted each year when a certain number of members receive an unannounced visit from an independent inspector (IFAT, 2004).

14 The promoters of the Max Havelaar label explained the initial challenges: "A different group rose up, on political principles, against the collaboration with roasters and supermarkets .... In World Shops, we put a great value on informing and raising awareness. Selling is a way to implicate citizens. A supermarket isn't a place of information and we question whether a consumer of a Max Havelaar product does so consciously .... A motion was adopted by a very small majority: it decided against the adoption of a Max Havelaar label" (Roozen and Van der Hoff, 2002, pp. 111-112, our translation).

15 In the words of Laure Waridel, co-founder of Équiterre, in the video "Le café à saveur equitable" (Gutierrez, 2000).
16 Équiterre is an NGO from Québec which is dedicated to building a citizens' movement by promoting individual and collective choices, such as fair trade, that are both environmentally and socially responsible (Équiterre, 2005).

17 According to these principles, one should favour products that are sold without packaging (Nude), are organic (Natural), are produced locally (Not-far), and are produced according to fair trade criteria (Just).

\section{Acknowledgements}

We would like to thank the Fonds québécois de la recherche sur la société et la culture (FQRSC) who financed the research on which this article is based, as well as our colleagues Olga Navarro-Flores and Marie-France Turcotte for their comments, ideas, and participation in all the stages of our reflection. We also would like to thank Annelies Hodge for the translation.

\section{References}

Auroi, C.: 2000, 'Le commerce équitable, un créneau potentiel pour les petits producteurs des pays en voie de développement', Économies et Société, Série Système agroalimentaires 24(10-11), 199-211.

Barrat Brown, M. and S. Adam: 1999, 'Le commerce équitable dans les échanges Nord-Sud', in J. Defourny, P. Develtere and B. Fonteneau (eds.), L'économie sociale au Nord et au Sud, pp. 105-122.

Bowen, B.: 2001, 'Let's Go Fair', Fair Trade Yearbook 2001 (Gand, EFTA).

Bucolo, E.: 2003, 'Le commerce équitable', Economie Solidaire et Démocratie, Hermès 36, 109-118.

Buccolo, E.: 2000, Le commerce équitable, coll. Les notes de l'Institut Karl Polanyi (Impatiences démocratiques, Arles, France).

Cashore, B.: 2002, 'Legitimacy and the Privatization of Environmental Governance: How Non-State MarketDriven Governance Systems Gain Rule-Making Authority', Govemance: An International Joumal of Policy, Administration, and Institutions 15(4), 503-529.

Champion, E.: 2003, 'De la responsabilité sociale corporative à la citoyenneté corporative: l'entreprise en quête de légitimité pour assurer un nouveau rôle social', Symposium international sur l'équité, l'efficience ou l'éthique: les codes de conduite et la régulation sociale de l'entreprise mondialisée (organized by CRIMT, Montréal, HEC Montréal, 30 April-2 May). 
Cohen, J. L.: 1985, 'Strategy or Identity: New Theoretical Paradigms and Contemporary Social Movements', Social Research 52(4), 663-716.

Eder, K.: 1993, The Institutionalization of Social Movement. Towards a New Theoretical Problematic in Social-Movement Analysis? (European University Institute, Florence).

EFTA: 2001, Fair Trade Yearbook 2001 (Gand, EFTA).

Équiterre: 2005, Homepage, available online at: http:// www.equiterre.org/. Accessed on 25 October 2005.

FLO: 2004, Homepage, available online at: http:// www.fairtrade.net. Accessed on 3 April 2004.

Gendron, C.: 2001, 'Émergence de nouveaux mouvements sociaux économiques', Revue pour 172, 175181.

Gendron, C.: 2005, 'Mouvements sociaux', in J.-L. Laville and A. D. Cattani (eds.), Dictionnaire de l'autre économie (Desclée de Brouwer, Paris), pp. 395-402.

Gutierrez, G. and C. Garcia: 2000, Le café à saveur équitable, Montréal, Oxfam-Québec, Argus Film, $20 \mathrm{~min}$. $44 \mathrm{sec}$.

IFAT: 2003, A Brief History of the Fair Trade Movement, IFAT Briefings, available online at: http:// www.ifat.org/fairtrade-res2.html. Accessed on 31 March 2004.

IFAT: 2004, Homepage, available online at: http:// www.ifat.org. Accessed on 3 April 2004.

Kocken, M.: 2003, Fifty Years of Fair Trade: A Brief History of the Fair Trade Movement, available online at: www.gepa3.de/download/gepa_Fair_Trade_history_ en.pdf. Accessed on 12 July 2005.

Latouche, S.: 2000, 'De l'éthique sur l'étiquette au juste prix, Aristote, les SEL et le commerce équitable', Revue du Mauss 15, 346-358.

Le Velly, R.: 2004, Le commerce équitable: des échanges marchands contre le marché et dans le marché. Unpublished thesis, Université de Nantes, Nantes.

Lemaigre, T. and P. Verbeeren: 1997, 'The Social Economy and Fair Trade', Agence Alter et Université de Liège.

Littrell, M. A. and M. A. Dickson (eds.): 1999, Social Responsibility in the Global Market: Fair Trade of Cultural Products (Sage, Thousand Oaks, California).

Low, W. and E. Davenport: 2005, 'Postcards from the Edge: Maintaining the "Alternative" Character of Fair Trade', Sustainable Development 13, 143-153.

Malservisi, M. and I. Faubert-Mailloux: 2000, Le commerce équitable (Chaire de coopération Guy-Bernier, Montréal).

Maurais, L. and M.-A. Lafrance: 2003, 'Une certification environnementale comme objet de régulation sociale: le cas du secteur forestier', Symposium international sur l'équité, l'efficience ou l'éthique: les codes de conduite et la régulation sociale de l'entreprise mondialisée, organized by CRIMT, Montréal, HEC Montréal, 30 April-2 May.

Melucci, A.: 1983, 'Mouvements sociaux, mouvements post-politiques', Revue internationale d'action communautaire 10(50), 13-30.

Micheletti, M.: 2003, Political Virtue and Shopping: Individuals, Shopping and Collective Action (Palgrave Macmillan, New York).

Offe, C.: 1985, 'New Social Movements: Challenging the Boundaries of Institutional Politics', Social Research 52(4), 817-868.

Office of the Commissioners for Khadi and Village Industries: 2005, Khadi: Khadi and Freedom Movement, available online at: http://www.kvic.org.in/v4/ KHADI2.ASP. Accessed on 23 August 2005.

O'Rourke, D.: 2000, Monitoring the Monitors: $A$ Critique of Pricewaterhousecoopers (Pu,C) Labor Monitoring, available online at: http://web.mit.edu/dorourke/www/PDF/ pwc.pdf. Accessed on 15 December 2005.

Perna, T.: 2000, 'La réalité du commerce équitable', La Revue du MAUSS 15, 359-372.

Renard, M.-C.: 2003, 'Fair Trade: Quality, Market and Conventions', Joumal of Rural Studies 19, 87-96.

Roozen, N. and F. Van der Hoff : 2002, L'aventure $d u$ commerce équitable. Une altemative à la mondialisation (Éditions JC Lattès, Paris).

SERRV: 2005, 'About Us: History', available online at: www.serrv.org/about/index.php? category_id=1317. Accessed on 12 July 2005.

SOLAGRAL: 2002, État des lieux et enjeux du changement d'échelle du commerce équitable: typologie des filières, marchés de consommation, gouvernance intemationale et cohérence globale du commerce équitable (SOLAGRAL, Paris).

Stark, A.: 1993, 'What's the Matter with Business Ethics?', Harvard Business Review 3, 38-48.

Stolle, D., M. Hooghe and M. Micheletti: 2003, 'Political Consumerism: A New Phenomenon of Political Participation?', an exploratory study in Canada, Belgium and Sweden, ECPR joint session, Edinburgh, 28 March-2 April.

Touraine, A.: 1973, Production de la société (Éditions du Seuil, Paris).

Touraine, A.: 1978a, 'Théorie et pratique d'une sociologie de l'action', Sociologie et Société 10(2), 149-188.

Touraine, A.: 1978b, La voix et le regard (Seuil, Paris).

Transfair: 2001, Homepage, available online at: http:// www.transfair.ca/q/info-fra.html. Accessed on 14 May 2001. 
Veit, P.: 1997, Commerce équitable entre l'Europe et le Tiers Monde, available online at: http://www.globenet.org/ horizon-local/astm/as68eq.html. Accessed on 30 March 2004.

Waridel et al.: 1998, L'En Vert de l'assiette. Un enjeu alimen...Terre (Éditions Les Intouchables, Québec).
Chaire de responsabilite sociale et de developement durable,

Universite du Quebec a Montreal, Ecole des Sciences de la Gestion, Bureau R-2885, 315, rue Sainte-Catherine Est, Montreal, Quebec, Canada E-mail: bisaillon.veronique@uqam.ca 